Terbit online pada laman web jurnal : http://teknosi.fti.unand.ac.id/

Jurnal Nasional Teknologi dan Sistem Informasi

ISSN (Print) 2460-3465 | ISSN (Online) 2476-8812 |

Studi Kasus

\title{
Pembangunan Sistem Informasi Rawat Jalan Berbasis Web dengan Fitur Mobile pada Puskesmas Tarok Kota Payakumbuh
}

\author{
Dini hariyati ${ }^{1}$, Ricky Akbar ${ }^{2}$ Meza Silvana ${ }^{2}$ \\ ${ }^{1}$ Mahasiswa Jurusan Sistem Informasi Universitas Andalas, Padang 25163, Indonesia \\ ${ }^{2}$ Dosen Jurusan Sistem Informasi Universitas Andalas, Padang 25163, Indonesia
}

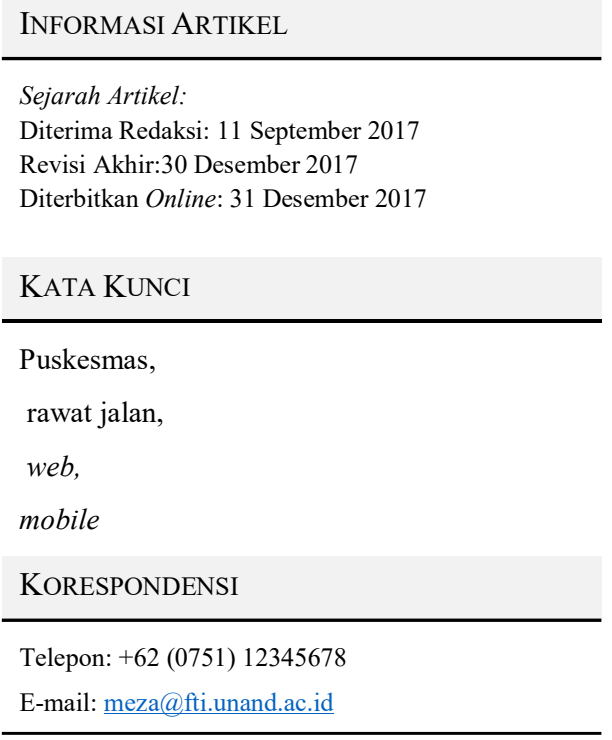

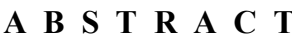

\begin{abstract}
The Center for Public Health (Puskesmas) serves as the primary health service center in outpatient services. One of them is Tarok Puskesmas which is one of the public health centers in Payakumbuh. Currently the outpatient service system in Tarok Puskesmas is still done manually so that there is often a long process of information exchange or the occurrence of misinformation between sections in the puskesmas. Therefore, an application is required to improve the system by designing and building a web-based information system using mobile features. Development methods on this system use waterfall method and application testing using blackbox testing method. The system is designed by analyzing the needs of the current system with three functionalities, ie viewing the history of patient visits, viewing medical records, and viewing reports of puskesmas that can be described by contex diagrams in seven entities, ie patients, admissions officers, policemen, pharmacists, Doctors, and leaders. This app is designed using a PostgreSQL database. This outpatient information system database has eleven tables, ie patient table, visit table, traffic_transaction table, family_name table, drug table, employee table, access table, poly table, disease table, preset table, and transaction table. The test results show that the implementation results have been in accordance with the functional requirements of system applications.
\end{abstract}

\section{PENDAHULUAN}

Puskesmas merupakan fasilitas pelayanan kesehatan yang menyelenggarakan upaya kesehatan masyarakat dan upaya kesehatan perseorangan tingkat pertama di wilayah kerjanya. Peranan puskesmas sangat membantu dalam usaha untuk meningkatkan kualitas kesehatan masyrakat [1]. Puskesmas Tarok merupakan salah satu instansi pemerintahan di bidang kesehatan yang peranannya sangat penting dalam meningkatkan kesehatan masyarakat di Kota Payakumbuh. Dalam memberikan layanan rawat jalan pada pasien, alur proses bisnis yang dilakukan pada Puskesmas Tarok masih dilakukan secara terpisah dan tidak terekap dengan rapi, sehingga membutuhkan waktu yang lama dalam pelaksaannya. Salah satu masalah yang sering dihadapi dalam memberikan layanan rawat jalan pada Puskesmas Tarok yaitu proses pelayanan yang membutuhkan waktu yang lama, seperti mencari buku rekam medis pasien, pencatatan jumlah obat yang tersedia digudang dan lain sebagainya, sehingga dibutuhkan sistem yang lebih baik dalam menjalankan proses bisnis untuk mengatasi masalah tersebut (wawancara personal, 22 September 2016). Berdasakan permasalahan ini, perlu dibangun

https://doi.org/10.25077/ TEKNOSI.v3i3.2017.353-359 sebuah sistem informasi rawat jalan yang terintegrasi yang dapat digunakan untuk membantu pegawai puskesmas dalam menjalankan proses bisnis yang lebih baik. Pemanfaatan teknologi informasi ini merupakan salah satu keunggulan kompetitif yang dimiliki oleh puskesmas dalam bersaing dengan puskesmas-puskesmas lainnya. keunggulan kompetitif lainnya adalah dengan memanfaatkan aplikasi berbasis mobile. Aplikasi berbasis mobile yang dapat diakses melalui smartphone ini memungkinkan pengguna dapat mengakses informasi yang dibutuhkan dimana pun dan kapan pun. Teknologi mobile ini dapat memudahkan pimpinan puskesmas memantau sistem rawat jalan melalui laporan yang dihasilkan melalui fitur mobile tidak terikat waktu.

Penelitian yang telah dilakukan terkait sistem informasi rawat jalan, yaitu perancangan sistem informasi pelayanan medis rawat jalan poliklinik kebidanan dan kandungan pada RSUD Kota Batam, aplikasi ini telah mampu meminimalisir kesalahan yang terjadi dalam pelayanan rawat jalan. Biasanya kesalahankesalahan yang sering terjadi seperti pengentrian data, duplikasi data dan kesalahan-kesalahan lain yang disebabkan oleh human error. Penelitian-penelitian di atas membuat aplikasi yang dapat membantu petugas mendapatkan informasi laporan secara cepat,

Attribution-NonCommercial 4.0 International. Some rights reserved 
serta mempermudah proses rekam medis,membantu efisiensi pelayanan instalasi rawat jalan, membantu proses pengelolaan data rawat jalan[13]. Oleh karena itu pada paper ini penelitian yang dilakukan adalah membangun sistem informasi rawat jalan berbasis web dengan menggunakan fitur mobile. Sistem ini diharapkan dapat mempermudah petugas administrasi puskesmas dalam mengelola data pasien dan dapat membantu pihak Puskesmas dalam menangani permasalahan layanan rawat jalan, sehingga dapat membantu proses pengambilan keputusan yang baik.

\section{TINJAUAN PUSTAKA}

\subsection{Sistem Informasi}

Sistem informasi adalah suatu sistem di dalam organisasi yang mempertemukan kebutuhan pengelolaan transaksi harian, mendukung operasi, bersifat manajerial, dan kegiatan strategi dari suatu organisasi[5]. Sistem informasi adalah suatu sistem yang terdapat di dalam sebuah organisasi yang saling berintegrasi dan bekerja sama satu sama lain untuk mencapai tujuan yang sama. Sistem informasi memiliki beberapa komponen yaitu blok masukan, blok model, blok keluaran, blok teknologi, blok basis data, blok kendali[6]. Jadi, sistem informasi adalah suatu sistem yang saling terintegrasi dan bekerja sama untuk mengumpulkan, memroses, menyimpan dan menyebar informasi untuk membantu sebuah organisasi dalam pengendalian sistem untuk mencapai tujuan organisasi.

\subsection{Puskesmas}

Puskesmas adalah fasilitas pelayanan kesehatan yang menyelenggarakan upaya kesehatan masyarakat dan upaya kesehatan perseorangan tingkat pertama yang mengutamakan upaya promotif dan preventif, untuk mencapai derajat kesehatan masyarakat yang setinggi-tingginya diwilayah kerjanya[1]. Salah satu upaya pelayanan yang diberikan puskesmas kepada masyarakat adalah perencanaan, pelaksanaan, evaluasi, pencatatan, dan pelaporan yang dirangkum dalam suatu sistem. Puskesmas bertugas untuk melaksanakan kebijakan kesehatan demi tercapainya tujuan pembangunan kesehatan di wilayah kerjanya dalam rangka mendukung terwujudnya kecamatan sehat. Selain itu, puskemas merupakan salah satu sarana untuk pendidikan tenaga kesehatan.

\subsection{Rawat Jalan}

Rawat jalan merupakan salah satu bentuk upaya pelayanan kesehatan perseorangan tingkat pertama. Pelayanan rawat jalan adalah salah satu unit kerja yang terdapat di puskesmas yang melayani pasien berobat jalan dan memberikan pelayanan lebih dari 24 jam. Rawat jalan adalah pelayanan terhadap orang yang masuk puskesmas, untuk keperluan observasi, diagnosa, pengobatan, rehabilitasi medik, dan pelayanan kesehatan lainnya tanpa tinggal diruang rawat inap. Sedangkan pelayanan rawat jalan yaitu pelayanan yang diberikan di unit pelaksanaan fungsional rawat jalan yang terdiri dari poliklinik umum dan poliklinik spesialis serta unit gawat darurat[7].

\subsection{Rekam Medis}

Rekam medis adalah berkas yang berisikan catatan dan dokumen tentang identitas pasien, pemeriksaan, pengobatan, tindakan, dan pelayanan lain yang telah diberikan dokter kepada pasien[8]. Catatan-catatan dan dokumen-dokumen tersebut sangat penting untuk pelayanan pasien, karena dapat memberikan informasi

354 Dini Hariyati dalam menentukan keputusan, baik untuk pengobatan, penanganan dan tindakan medis lainnya. Informasi rekam medis pasien harus dijaga kerahasiaannya oleh dokter, pimpinan tempat layanan kesehatan, tenaga kesehatan tertentu, dan petugas pengelola, tetapi dapat dibuka dalam hal-hal tertentu. Sebagaimana diatur dalam Peraturan Menteri Kesehatan RI No. 269 Tahun 2008 tentang Rekam Medis Bab IV pasal 10, informasi tentang identitas, diagnosis, riwayat penyakit, riwayat pemeriksaan dan riwayat pengobatan dapat dibuka dalam hal:

a. Untuk kepentingan kesehatan pasien,

b. Memenuhi permintaan aparatur penegak hukum dalam rangka penegakan hukum atas perintah pengadilan,

c. Permintaan dan/atau persetujuan pasien sendiri,

d. Permintaan institusi/lembaga berdasarkan ketentuan perundang-undangan, dan

e. Untuk kepentingan penelitian, pendidikan, dan audit medis, sepanjang tidak menyebutkan identitas pasien.

\subsection{PHP}

PHP merupakan singkatan dari Hypertext Processor yang digunakan sebagai bahasa script server-side dalam pengembangan web yang disisipkan pada dokumen HTML. Dengan penggunaan PHP, memungkinkan dapat membuat web yang dinamis sehingga pemeliharaan situs web dapat menjadi lebih mudah dan efisien[9].

\subsection{PostgreSQL}

PostgreSQL merupakan salah satu dari sejumlah database besar yang menawarkan skalabilitas, keluwesan, dan kinerja yang tinggi[10]. PostgreSQL adalah sebuah database relasional yang termasuk dalam kategori perangkat lunak open source. Penggunaan PostgreSQL sangat meluas diberbagai platform dan memiliki arsitektur yang luwes, sehingga didukung oleh banyak antarmuka ke berbagai bahasa pemrograman.

\subsection{HTML}

HTML (Hyper Text Markup Language) merupakan sebuah bahasa scripting yang berguna untuk menuliskan halaman web[11]. Pada web, HTML dijadikan sebagai bahasa script dasar yang berjalan bersama berbagai bahasa scripting pemograman lainnya.

\subsection{BPMN}

Business Process Modelling Notation (BPMN) adalah standar untuk memodelkan proses bisnis. BPMN dirancang untuk mudah digunakan dan dipahami, serta untuk memodelkan proses bisnis yang kompleks dan spesifik[12].

\subsection{Use Case}

Use case adalah konstruksi untuk mendeskripsikan bagaimana sistem akan terlihat dimata pengguna potensial. Use Case adalah tugas yang dilakukan oleh actor. Sekumpulan use case biasanya dikelompokkan dalam suatu group yang disebut System Boundary[13]. Use case diagram membantu dalam penyusunan requirement sebuah sistem, mengkomunikasikan rancangan dengan klien, dan merancang test case untuk semua feature yang ada pada sistem[14]. Use case menjelaskan secara sederhana fungsi sistem dari sudut pandang user.

\subsection{Basic4Android}

Basic4Android sendiri merupakan tools RAD yang terdiri dari framework, library, dan IDE yang terintegrasi dengan java dan

https://doi.org/10.25077/ TEKNOSI.v3i3.2017.353-359 
android SDK. Basic4Android didesain sedemikian rupa sehingga memudahkan developer untuk mengembangkan aplikasi android menggunakan bahasa Visual Basic dan IDE yang mudah untuk digunakan. Basic4Android juga menyediakan library-library lengkap untuk mengakses berbagai macam fitur yang ada pada smartphone seperti sensor, kamera, GPS, dan sebagainya[15].

\section{METODOLOGI}

Pada penelitian ini, sistem fitur mobile yang dibangun adalah layanan rawat jalan yaitu riwayat kunjungan pasien, hasil rekam medis pasien dan laporan kunjungan puskesmas dengan menggunakan smartphone android dengan minimum sistem operasi versi 4 (Kitkat). Sebelum membangun aplikasi terlebih dahulu dilakukan pengumpulan data. Metode pengumpulan data yang dilakukan adalah dengan melakukan studi lapangan yang terdiri dari observasi, wawancara Puskesmas Tarok, analisis dokumen, dan studi literatur.

Pada pembangunan sistem layanan rawat jalan ini, penulis menggunakan metode pengembangan sistem model waterfall yang dapat dilihat pada gambar 1 .

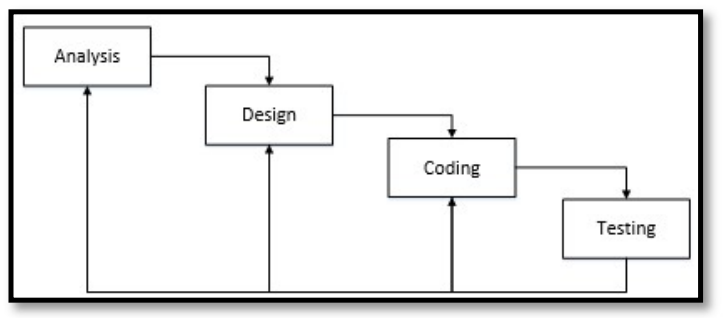

Gambar 1. Metode Waterfall[2]

Penelitian ini dapat dijelaskan dalam 4(empat) tahap, yaitu pertama, tahap analysis. Tahap ini merupakan proses mengidentifkasi dan mengevaluasi permasalahan-permasalahan yang terjadi, dan kebutuhan-kebutuhan yang diharapkan pada Puskesmas Tarok. Proses analisis sistem yang sedang berjalan digambarkan menggunakan BPMN. Kedua, tahap design. Tahap ini menentukan arsitektur sistem secara keseluruhan, desain pembuatan program perangkat lunak, dan prosedur pengkodean. Pada tahap ini dilakukan perancangan sistem yang terdiri dari perancangan ERD (Entity Relational Diagram), arsitektur perangkat lunak, perancangan antarmuka dengan menggunakan tools UML. Setelah itu dilakukan perancangan antarmuka untuk sistem informasi berbasis web dan untuk perangkat mobile. Ketiga tahap coding. Pada tahap ini, perancangan perangkat lunak direalisasikan sebagai satu set program atau unit program. Implementasi sistem dilakukan dengan menggunakan bahasa pemrograman PHP, HTML, javascript, dan database PostgreSQL. Dan keempat tahap testing. Pada tahap ini dilakukan pengujian perangkat lunak untuk memastikan semua persyaratan sistem telah terpenuhi dan memastikan bahwa keluaran memberikan hasil yang sesuai dengan kebutuhan. Dalam penelitian ini pengujian sistem dilakukan menggunakan pengujian black-box. Untuk membandingkan hasil pengujian sesuai dengan fungsional yang telah ditentukan.

\section{HASIL DAN PEMBAHASAN}

\subsection{Analisis Kebutuhan sistem}

Pada tahap ini penelitian dimulai dengan menganalisis kebutuhan sistem dari data-data yang telah didapatkan. Adapun kebutuhan fungsional aplikasi sistem rawat jalan

Puskesmas Tarok yang didapatkan adalah sebagai berikut:

https://doi.org/10.25077/ TEKNOSI.v3i3.2017.353-359 a. Pimpinan dapat melihat laporan yang dikeluarkan puskesmas, seperti laporan data obat, laporan data pegawai, laporan riwayat kunjungan, dan laporanrekam medis.

b. Petugas admisi dapat mengelola data pasien, mengelola data kepala keluarga, menambahkan kunjungan, mencetak nomor antrian, mencetak kartu berobat, dan membuat laporan.

c. Petugas poli/perawat dapat mengelola hasil pemeriksaan fisik.

d. Dokter dapat mengelola data hasil pemeriksaan penyakit (diagnosa dan tindakan medis), mengelola resep obat dan membuat surat rujukan.

e. Apoteker dapat mengelola data obat, melihat resep obat, dan ACC resep obat.

f. Pasien dapat melihat riwayat kunjungan dan rekam medis pasien itu sendiri.

g. Admin mengelola data poli, data pegawai, data akses user, dan melihat laporan puskesmas.

Kemudian dari kebutuhan fungsional ini digambarkan dengan bentuk use case diagram dengan aktor-aktor yang terlibat di dalam penggunaan sistem informasi rawat jalan di Puskesmas Tarok dan aktivitas-aktivitas yang dilakukan para aktor tersebut di dalam sistem. Pada sistem penjadwalan kuliah yang baru, terdapat tujuh aktor yang terlibat di dalam dalam sistem yang terdiri dari admin, petugas admisi, pasien, dokter, petugas poli, pimpinan puskesmas dan apoteker. Aktivitas-aktivitas yang dapan dilakukan oleh para aktor dapat dilihat pada Gambar 2.

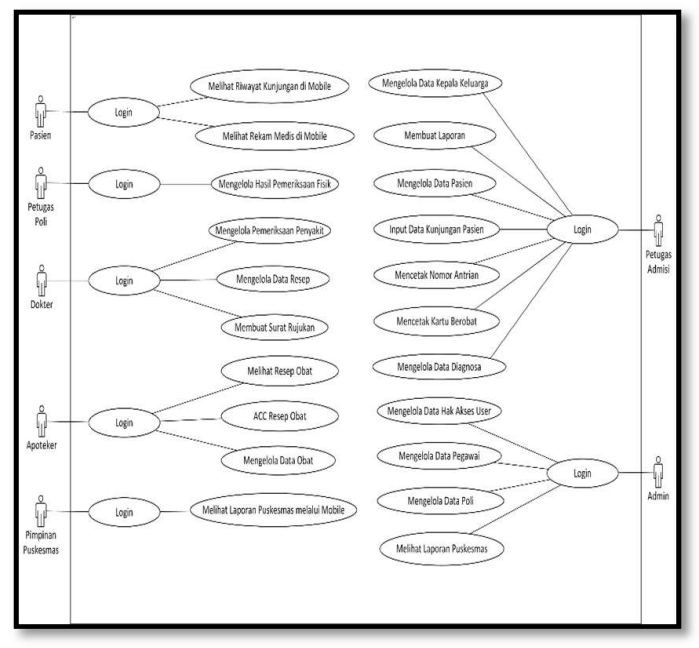

Gambar 2. Usecase Diagram

Kemudian membuat Context diagram yang menggambarkan aliran data antara entitas dan sistem. Pada penelitian ini terdapat tujuh entitas, yaitu pasien, petugas admisi, petugas poli, apoteker, dokter, dan pimpinan, dapat dilihat pada Gambar 3. 


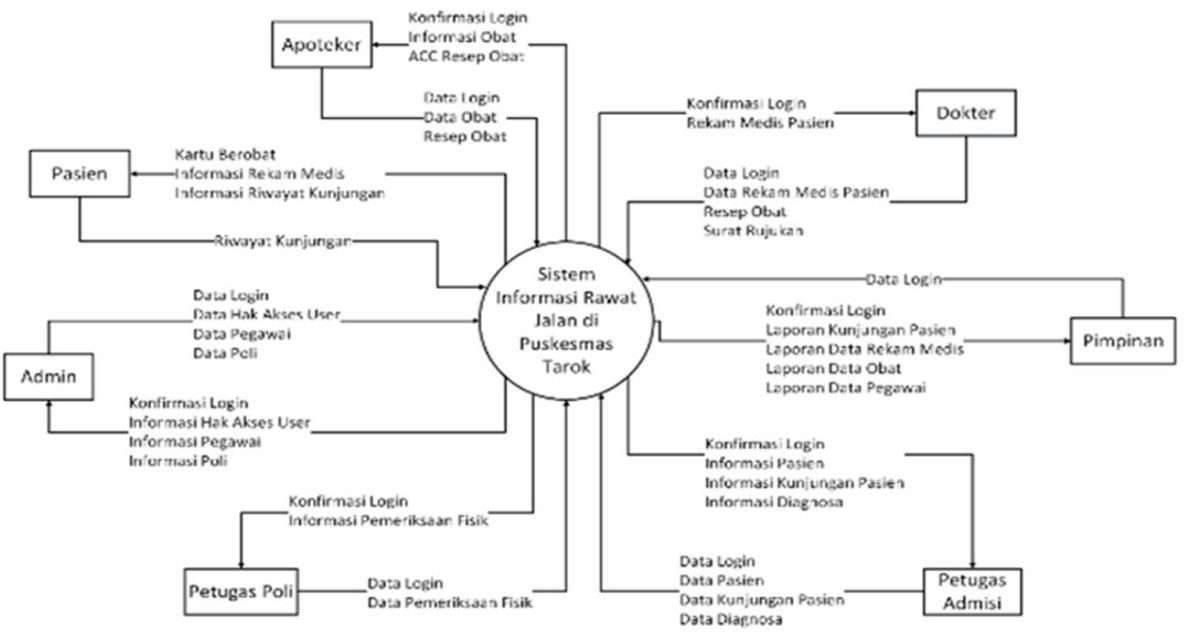

Gambar 3. Context Diagram

Setelah itu membuat Data Flow Diagram (DFD) merupakan representasi grafik yang menggambarkan aliran informasi dari sistem atau perangkat lunak. DFD dibagi menjadi beberapa level untuk mempresentasikan aliran informasi yang detail. DFD level 1 terjadi dekomposisi terhadap proses yang besar menjadi proses yaitu mengelola hasil pemeriksaan, mengelola data resep obat, mengelola data obat, mengelola data kepala keluarga, mengelola data pasien, mengelola data poli, mengelola data pegawai, mengelola data hak akses user, menambah kunjungan, melihat laporan, mencetak nomor antrian, dan mencetak kartu berobat dimana masingmasing proses berhubungan dengan entitas maupun tabel. Perancangan data flow diagram dapat dilihat pada gambar 4.

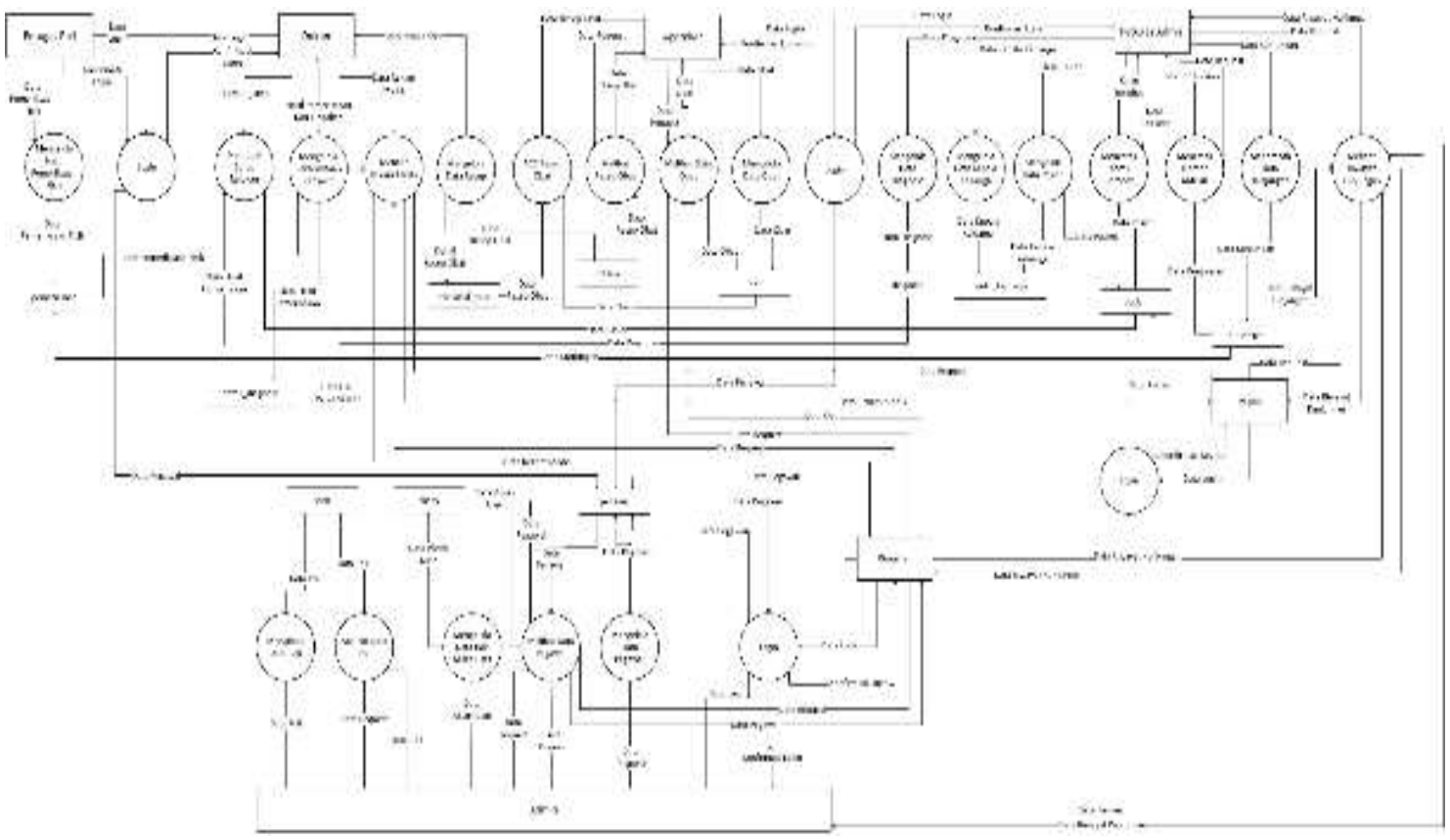

Gambar 4. Data Flow Diagram

\subsection{Perancangan Sistem Aplikasi}

Perancangan sistem aplikasi dibangun dengan merancang arsitektur aplikasi, dilanjutkan dengan perancangan database, perancangan proses dan perancangan antarmuka. 


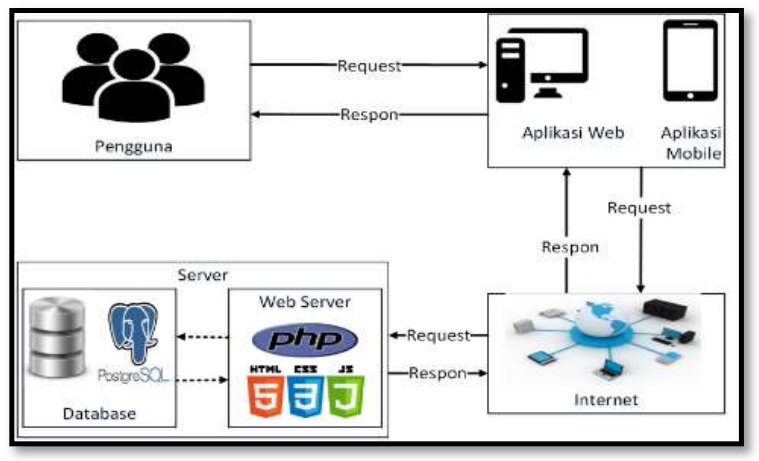

Gambar 5 Arsitektur Aplikasi

Arsitektur aplikasi pada penelitian ini terdiri dari perhubungan antar komponen pengguna dari dengan aplikasi web/mobile yang memiliki akses dengan internet, dimana akses ini memungkinkan pengguna untuk dapat mendapatkan informasi yang dibutuhkan dari server (data warehouse) terkait data rawat jalan puskesmas tarok. Arsitektur aplikasi sistem rawat jalan puskesmas tarok dapat dilihat pada gambar 5 .

Database sistem informasi rawat jalan terdiri dari sebelas tabel, yaitu pasien, kunjungan, transaksi_kunjungan, kartu_keluarga, obat, pegawai, akses, poli, penyakit, resep, dan transaksi_obat. ERD untuk sistem informasi rawat jalan di Puskesmas Tarok digambarkan pada gambar 6.

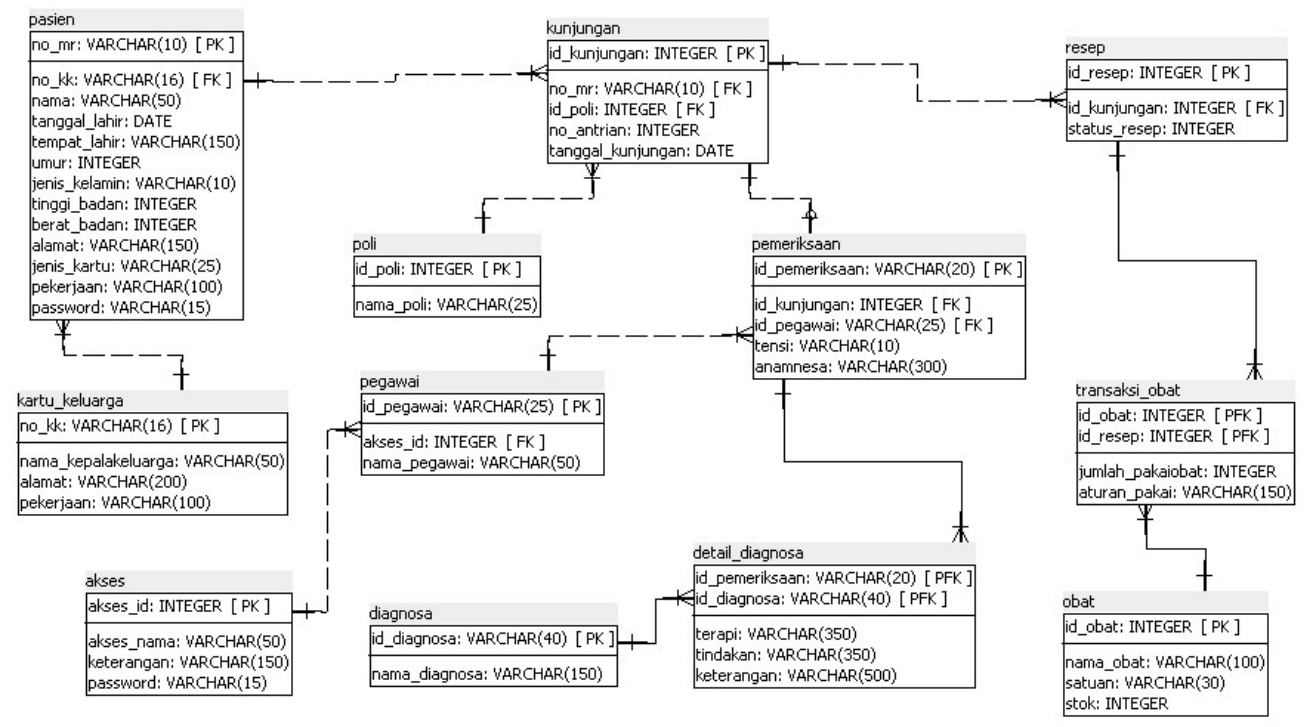

Gambar 6 Perancangan Basis Data

Perancangan proses untuk aplikasi disajikan dalam bentuk skenario. Skenario ini menggambarkan urutan aksi dan reaksi antara pengguna dan sistem yang terapat dalam use case diagram. Skenario menambah data pasien dapat dilihat pada tabel 1 .

Tabel 1. Skenario Menambah Data Pasien

\begin{tabular}{llll}
\hline Usecase name & Menambah data pasien \\
\hline Participating actor & Petugas Admisi \\
\hline Flow of events & 1. & $\begin{array}{l}\text { Petugas menekan menu Cek } \\
\text { Pasien, klik Daftar Baru } \\
\text { Sistem menampilkan form } \\
\text { tambah data pasien untuk } \\
\text { pendaftaran pasien }\end{array}$ \\
& 3. & $\begin{array}{l}\text { Petugas mengisi form dan } \\
\text { tekan tombol Simpan } \\
\text { Sistem menyimpan data } \\
\text { pasien }\end{array}$ \\
\hline
\end{tabular}

https://doi.org/10.25077/ TEKNOSI.v3i3.2017.353-359

\begin{tabular}{lll}
\hline Entry condition & & Aktor telah login ke sistem \\
\hline Exit conditions & Sistem menyimpan data pasien \\
\hline Alternative scenario & 1. & $\begin{array}{l}\text { Petugas menekan menu Cek } \\
\text { Pasien, klik Daftar Baru } \\
\text { Sistem menampilkan form } \\
\text { untuk pendaftaran pasien } \\
\text { Petugas mengisi form tambah } \\
\text { data pasien dan klik button }\end{array}$ \\
& 4. & $\begin{array}{l}\text { Simpan } \\
\text { Sistem memeriksa valid atau } \\
\text { tidaknya data yang diisi }\end{array}$ \\
5. & $\begin{array}{l}\text { Sistem menampilkan } \\
\text { pemberitahuan data harus diisi } \\
\text { Petugas mengisi form tambah } \\
\text { data pasien yang belum diisi } \\
\text { dan menekan tombol Simpan }\end{array}$ \\
7. & Sistem menyimpan data pasien \\
\hline
\end{tabular}


Perancangan antarmuka aplikasi web dirancang menggunakan aplikasi mockflow, sedangkan rancangan tampilan aplikasi mobile dirancang menggunkan fitur designer pada Basic4Android. Perancangan antarmuka untuk aplikasi web dapat dilihat pada gambar 7 dan perancangan antarmuka untuk aplikasi mobile dapat dilihat pada gambar 8 .

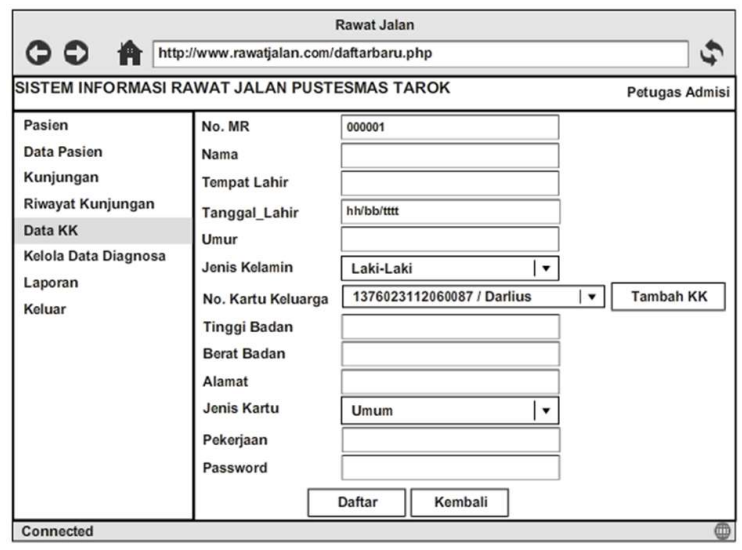

Gambar 7 Perancangan antarmuka menambah data pasien

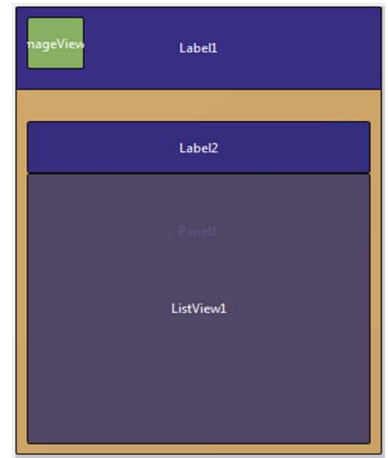

Gambar 8 Melihat Laporan Data Obat

\subsection{Implementasi Sistem}

Implementasi sistem dilakukan dengan melakukan Implementasi AntarmukaImplementasi antarmuka menggambarkan tampilan dari aplikasi yang dibangun. Implementasi antarmuka ini mencakup antarmuka aplikasi web dan mobile. Implementasi halaman menambah data pasien dapat dilihat pada gambar 9 dan implementasi melihat laporan data obat dapat dilihat pada gambar 10.

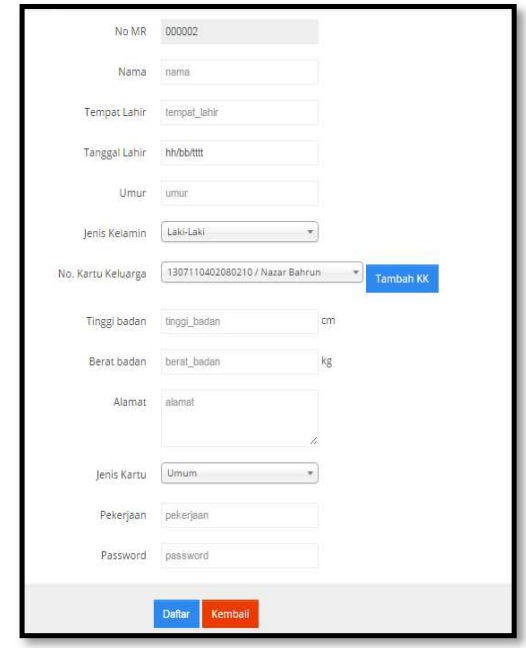

Gambar 9 Implementasi Menambah Data Pasien

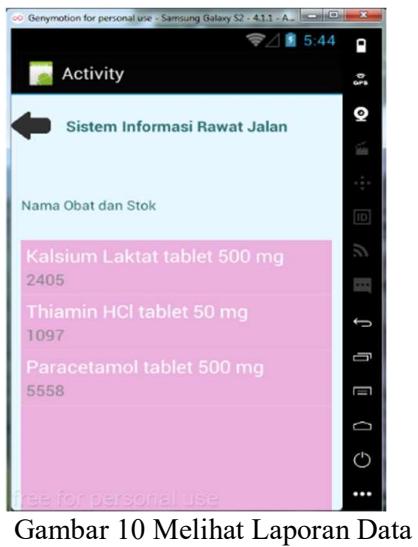

\subsection{Pengujian sistem}

Pengujian aplikasi dilakukan dengan metode blackbox testing, yaitu melihat kesesuaia masukan ke sistem dan keluaran dari sistem. Jika keluaran sistem sama dengan hasil yang diharapkan, maka aplikasi tersebut berhasil dibangun. Pengujian yang akan dilakukan yaitu pengujian menambah data pasien. Tahapan pengujian dapat dilihat pada tabel 2 .

Tabel 2. Tahapan Pengujian Menambah Data Pasien

\begin{tabular}{ll}
\hline \multicolumn{2}{l}{ Kondisi dan hasil uji berhasil (sukses) } \\
\hline Tambah data pasien \\
\hline Data masukan & Data lengkap pasien \\
\hline Yang diharapkan & $\begin{array}{l}\text { Data tersimpan dan dapat dilihat pada } \\
\text { data pasien }\end{array}$ \\
\hline Pengamatan & $\begin{array}{l}\text { Data tersimpan dan dapat dilihat pada } \\
\text { data pasien }\end{array}$ \\
\hline Kesimpulan & \multicolumn{1}{l}{ Sesuai } \\
\hline Kondisi dan hasil uji (gagal) \\
\hline Data masukan & Data pasien tidak lengkap \\
\hline Yang diharapkan & $\begin{array}{l}\text { Data tidak tersimpan dan tidak tampil } \\
\text { pada data pasien }\end{array}$ \\
\hline Pengamatan & $\begin{array}{l}\text { Data harus diisi dengan lengkap } \\
\text { sebelum disimpan }\end{array}$ \\
\hline Kesimpulan & Sesuai \\
\hline
\end{tabular}


Hasil pengujian aplikasi web dapat dilihat pada gambar 11 dan gambar 12, hasil pengujian manual pada basis data PostgrSQL dapat dilihat pada gambar 13, dan pengujian tambah data pasien kondisi gagal dapat dilihat pada gambar 14

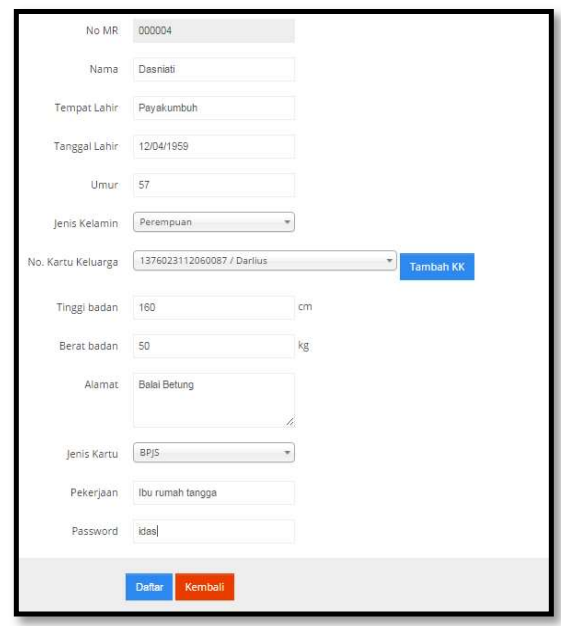

Gambar 11 Pengujian Menambah Data Pasien

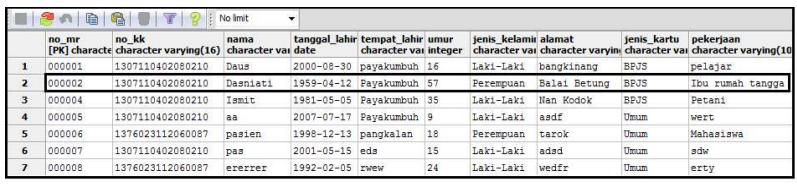

Gambar 12 Pengecekan Tambah Data Masuk Kondisi Sukses pada Database

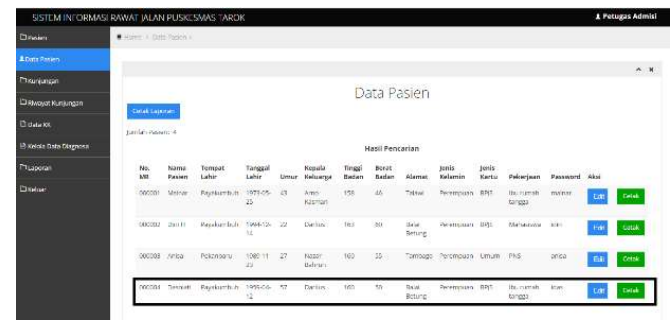

Gambar 13 Hasil Pengujian Menambah Data Pasien

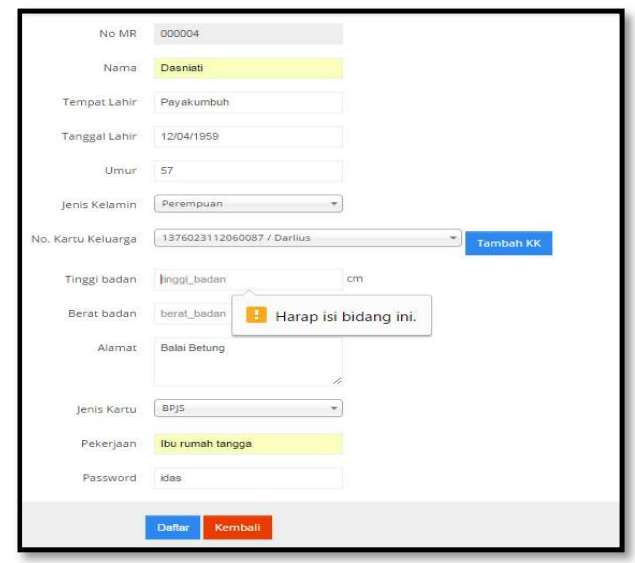

Gambar 14 Pengujian Tambah Data Pasien dengan Kondisi Gagal

\section{KESIMPULAN DAN SARAN}

Aplikasi sistem informasi rawat jalan berbasis web dengan fitur mobile pada Puskesmas Tarok Kota Payakumbuh telah berhasil dibangun. Aplikasi mobile memiliki tiga fungsional, yaitu melihat riwayat kunjungan, melihat rekam medis, dan melihat laporan puskesmas. Aplikasi berbasis mobile telah dapat diakses melalui smartphone ini memungkinkan pengguna dapat mengakses informasi yang dibutuhkan dimana pun dan kapan pun. Teknologi mobile ini dapat memudahkan pimpinan puskesmas memantau sistem rawat jalan melalui laporan yang dihasilkan melalui fitur mobile.

\section{DAFTAR PUSTAKA}

[1] Peraturan Menteri Kesehatan Republik Indoensia Nomor 75 Tahun 2014 tentang Pusat Kesehatan Masyarakat.

[2] Pressman, R. S. 2010. Software Engineering: A Practitioner's Approach, 7/e, RS Pressman \& Associates. Inc., McGraw-Hill, ISBN, 73375977.

[3] Raymond, McLeod Jr. 2001. Sistem Informasi Manajemen. Jakarta :Erlangga

[4] Jogiyanto, H.M. (2005).Analisis dan Desain Sistem Informasi: Pendekatan Terstruktur Teori dan Praktik Aplikasi Bisnis. Yogyakarta: Andi Offset.

[5] Hutahaean, Jeperson. 2014. Konsep Sistem Informasi. Ed 1. Deepublish. Yogyakarta.

[6] Al Fatta, H. (2007). Analisis dan Perancangan Sistem Informasi untuk keunggulan bersaing perusahaan dan organisasi modern. Penerbit Andi.

[7] Keputusan Menteri Kesehatan Republik Indonesia Nomor 129 Tahun 2008 tentang Standar Pelayanan Minimal Rumah Sakit. Diakses tanggal 14 Maret 2016.

[8] Peraturan Menteri Kesehatan Republik Indonesia Nomor 269 Tahun 2008 tentang Rekam Medis. Diakses tanggal 1 Januari 2017.

[9] Suhartanto, M. (2012). Pembuatan Website Sekolah Menengah Pertama Negeri 3 Delanggu Dengan Menggunakan Php Dan Mysql. Speed-Sentra Penelitian Engineering dan Edukasi, 4(1).

[10] Sugiana, Owo. 2001. SQL dengan Postgres. PT RAB Linux Indonesia: Jakarta.

[11] Nugroho, Bunafit. 2008. Aplikasi Pemograman Web Dinamis Dengan PHP dan MySQL. Yogyakarta, Gava Media.

[12] Dewi, L. P., Indahyanti, U., \& Hari, Y. (2012). PEMODELAN PROSES BISNIS MENGGUNAKAN ACTIVITY DIAGRAM UML DAN BPMN (STUDI KASUS FRS ONLINE) (Doctoral dissertation, Petra Christian University).

[13] Imbar, R. V., \& Kurniawan, Y. (2015). 5. Perancangan Sistem Informasi Pelayanan Medis Rawat Jalan Poliklinik Kebidanan dan Kandungan pada RSUD Kota Batam. Jurnal Sistem Informasi, 7(1). Diakses tanggal 18 April 2016.

[14] Dharwiyanti, S., \& Wahono, R. S. (2003). Pengantar Unified Modeling Language (UML). Ilmu Komputer.com. Diakses tanggal 21 Januari 2016.

[15] Pratama, Febrinanda Endriz. 2014. Pembangunan Mobile GIS Wisata Alam Provinsi Sumatera Barat. Universitas Andalas. 